\title{
FROM THE DESK OF EDITOR in CHIEF
}

\author{
(Journal of Surgical Sciences, 2018; Vol.22, No. 1)
}

Dear Members,

It is my pleasure to greet you a very happy new year 2018. This is the first issue of our editorial team. We will try our best to improve the quality of the journal and uphold the journal in the international arena. I humbly request all the members of the society to send good quality research articles, review articles and case reports following the guideline thoroughly for the upcoming issues of the journal. I look forward for your active participation and all out support. Thank you all on behalf of the editorial team.

Professor Salma Sultana

Editor-in-Chief

Journal of Surgical Sciences.

Society of Surgeons of Bangladesh. 